\title{
ARTICLES
}

\section{ASSESS THE EFFECTIVENESS OF SELF-INSTRUCTIONAL MODULE ON KNOWLEDGE OF STAFF NURSES REGARDING MANAGEMENT OF BURN INJURY IN SURGICAL DEPARTMENT OF M.K.C.G, MCH, BERHAMPUR}

Ms. Madhusmita Sahoo*| Mrs. P. Laxmi Bai**

* Lecturer, DRIEMS School and College of Nursing, Odisha, India.

** Lecturer cum HOD (MSN), College of Nursing, Odisha, India. DOI: http://doi.org/10.47211/tg.2020.v07i03.005

\section{ABSTRACT}

Recovery from a burn injury requires a lot of work on the part of the client and significant others including health care professionals. The client's health can be resumed with both positive body and positive mind by effective management of Burn injury. The study was conducted with the objective to assess the knowledge of staff nurses regarding management of burn injury, to assess the effectiveness of self-instructional module (SIM) and to compare the effectiveness of SIM on knowledge of staff nurses regarding management of burn injury with their selected demographic variables. Data was collected by using purposive sampling by taking 50 samples from the surgical department of M.K.C.G, MCH, Berhampur. The data was analysed by calculating the mean percentage, standard deviation, $T$-test and chi-square. The findings revealed that prior to the implementation of self-instructional module mean score was (22.56 \pm 3.3 ) which is $56.4 \%$ of maximum knowledge score. Highest post-test mean score was $33.3 \pm 3.43$ which is $83.25 \%$ showing a difference of $26.85 \%$ of effectiveness. Area wise comparison of knowledge score shows that, during pre-test the highest mean score was $58.37 \%$ of the total score obtained from the area of burn wound care, physiotherapy and rehabilitation and the staff nurses were having lowest knowledge in the area of prevention, first aid treatment, and management of burn injury that is $52.61 \%$ of mean score. Highly Significant difference of $26.85 \%$ was found between pre- and post-test's knowledge score. Significant association was found between post-test knowledge score according to professional qualification, year of professional experience and year of experience in care of Burn patient. But no significant association was found according to age and previous source of knowledge.

Key Words: Assess, Effectiveness, Self-instructional module, knowledge, Staff Nurse, Surgical department, Burn injury, Management.

\section{ABOUT AUTHORS}

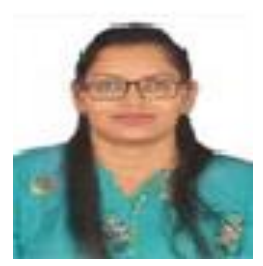

Author Miss Madhusmita Sahoo, M.Sc., Nursing (MSN) is a Lecturer in DRIEMS School and College of Nursing, Odisha, India. She has attended various State and National conferences and workshops.

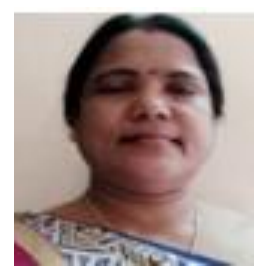

Mrs. P. Laxmi Bai is Senior Lecturer cum HOD, M.S.N. College of Nursing, Berhampur, Odisha. She has attended various National and International conferences and workshops. She has also few publications to her name. 


\section{ARTICLES}

\section{INTRODUCTION}

Burns are the most devastating condition encountered in medicine. A burn occurs when there is injury to the tissue of body caused by heat, chemicals, electric current or radiation. The resulting effects are influenced by the temperature of burning agent, duration of contact time and type of tissue that is injured.

A burn injury is an unforeseen event that includes a physical as well as a psychological trauma for the person afflicted. Clinical experience indicates that the intensity of pain often seems increase by wound infection. The study included 165 burn patients, 60 of whom were diagnosed with infection.

A burn injury is a type of injury to flesh or skin caused by heat, electricity, chemical, friction or radiation. Burn that affects only superficially is first degree burns; when damage penetrates into some of the underlying layers like dermis and subcutaneous tissue, it is a partial thickness or second degree burn. In a full thickness or third degree burn, the injury extends to all layers of the skin. A fourth degree burn, additionally involves injury to deeper tissues such as muscle or bone.

An acute burn wound is a complex and evolving injury. Extensive burns produce systemic consequences in addition to local tissue damage. Treatment of partial thickness burn wounds is directed towards promoting healing, and a wide variety of dressings are currently available. Improvements in technology and advances in understanding of wound healing have driven the development of new dressings. Dressing selection should be based on their effects on healing, but ease of application and removal, dressing change requirement, cost and patient comfort should also be considered.

Burns are a global public health problem accounting for an estimate 265000 deaths annually and a leading cause of morbidity, including prolonged hospitalisation, disfigurement and disability often with resulting stigma and rejection. In INDIA, 1million people are moderately or severely burnt every year. Non-fatal burn injuries are a leading cause of morbidity even though burns are preventable.

\section{NEED FOR THE STUDY}

Health is a primary need of every individual. The health care personnel should help the people for achieving their life and to meet their rights. Burn complications like post burn contracture creates disfigurement and annoyance in the patient. To relieve from those traumas, optimum nursing care is the key aid. Quality of life among burn patients can be possible without any kind of complications. It is possible by sufficient knowledge, skilful management and expertisation in providing burn wound care by nurses.

The disabilities can be minimised by effective burn management. Since the staff nurses are the key element of health care delivery system, adequate knowledge of staff nurses on burn management is essential. So it is felt that there is a need to conduct a study on the knowledge of staff nurses regarding management of burn injury.

\section{PROBLEM STATEMENT}

'A Study to assess the effectiveness of Self Instructional Module on knowledge of staff nurses regarding management of Burn injury in surgical department of M.K.C.G, MCH, Berhampur.'

\section{OBJECTIVES OF THE STUDY}

1. To assess the knowledge of staff nurses regarding management of burn injury in the surgical department of MKCG, MCH, Berhampur.

2. To assess the effectiveness of the self-instructional module (SIM) on knowledge of staff nurses regarding management of burn injury in the surgical department of $\mathrm{MKCG}, \mathrm{MCH}$, Berhampur.

3. To compare the effectiveness of SIM on knowledge of staff nurses regarding management of burn injury with their selected demographic variables in the surgical department of $\mathrm{MKCG}, \mathrm{MCH}$, Berhampur.

4. To find out association between post-test knowledge score of staff nurses regarding management of burn injury and their selected demographic variables in the surgical department of MKCG, $\mathrm{MCH}$, Berhampur. 


\section{ARTICLES}

\section{RESEARCH METHODOLOGY}

Research design: Quantitative research approach, one group pre-test post-test quasi experimental design $\left(o_{1} \times o_{2}\right)$ was selected.

\section{Variables:}

- Independent variable: Self-instructional module.

- Dependent variable: Knowledge of staff nurses regarding management of burn injury.

Setting of the study: The study was conducted in the surgical ward of M.K.C.G, MCH, Berhampur.

Population: Population consisted of staff nurses of M.K.C.G, MCH, Berhampur.

Sample: Staff nurses of the surgical ward of M.K.C.G, MCH, Berhampur.

Sample size: 50 (fifty)

Sampling technique: Purposive sampling technique

Tools: 1) Structured questionnaire divided into three areas.

2) Self-instructional module (SIM)

Validity: Validity of the tool was established in consultation with the guide and experts in the field of medical surgical nursing and statistics with $(r=0.82)$

\section{FINDINGS}

Highest Percentage, (54\%) of staff nurses came from the age group 25-35 years. Majority (82\%) of staff nurses were GNM qualified. Most of the staff nurses 34 (68\%) were having 1-5 years of professional experience. Most of the nurses i.e. 36 (72\%) were having $1-5$ years of experience in care of burn patients. Highest number, 40 (90\%) of them obtained information through books, journals, articles etc.

Table - 1: Comparison of pre- and post-test mean knowledge scores of Staff nurses regarding management of burn injury.

$(\mathrm{N}=50)$

\begin{tabular}{|c|c|c|c|c|c|c|c|c|c|}
\hline \multicolumn{10}{|c|}{ Knowledge score } \\
\hline SI. & Area of knowledge & \multirow{2}{*}{$\begin{array}{l}\text { Max. } \\
\text { score }\end{array}$} & \multicolumn{3}{|c|}{ Post- test } & \multicolumn{3}{|c|}{ Pre-test } & \multirow{2}{*}{$\begin{array}{l}\text { Difference } \\
\text { in mean \% }\end{array}$} \\
\hline & & & Mean & $\begin{array}{l}\text { Standard } \\
\text { deviation }\end{array}$ & $\begin{array}{c}\text { Mean } \\
\%\end{array}$ & Mean & $\begin{array}{l}\text { Standard } \\
\text { deviation }\end{array}$ & $\begin{array}{c}\text { Mean } \\
\%\end{array}$ & \\
\hline 1. & $\begin{array}{l}\text { Concept, sign \& symptoms, } \\
\text { diagnostic evaluation and } \\
\text { complication of burn injury }\end{array}$ & 11 & 9.36 & 1.24 & 85.09 & 6.34 & 1.68 & 57.63 & 27.49 \\
\hline 2. & $\begin{array}{l}\text { Prevention, first aid } \\
\text { treatment, fluid } \\
\text { management, pain } \\
\text { management and } \\
\text { nutritional management of } \\
\text { burn injury }\end{array}$ & 13 & 10.40 & 1.56 & 80.00 & 6.86 & 1.83 & 52.61 & 27.40 \\
\hline 3. & $\begin{array}{l}\text { Burn wound care, infection } \\
\text { control, wound closure, } \\
\text { physiotherapy and } \\
\text { rehabilitation }\end{array}$ & 16 & 13.54 & 1.61 & 84.62 & 9.34 & 2.16 & 58.37 & 26.32 \\
\hline & Overall total & 40 & 33.30 & 3.43 & 83.25 & 22.56 & 3.34 & 56.4 & 26.85 \\
\hline
\end{tabular}

Table-1 reveals that prior to the implementation of self-instructional module the mean score was (22.56 \pm 3.3 ) which is $56.4 \%$ of maximum knowledge score. The staff nurses had average knowledge regarding management of burn injury. Highest post-test mean score was $33.3 \pm 3.43$ which is $83.25 \%$ showing a difference of $26.85 \%$ of effectiveness and is indicative of having a very good knowledge 


\section{ARTICLES}

By using paired T-test, highly significant difference was found between pre- and post-test knowledge scores of staff nurses.

By using chi-square test, significant association was found between post-test knowledge score and the nurses' professional qualification, year of Professional experience and years of experience in care of Burn patients but no significant association was found with age and source of knowledge $(p<0.05)$.

\section{CONCLUSION}

Prior to the implementation of self-instructional module, the staff nurses had average knowledge regarding management of burn injury, which is $56.4 \%$ of maximum knowledge score whereas after implementation of selfinstructional module the staff nurses were found having good knowledge, $83.25 \%$ and the difference in mean percentage was $26.85 \%$. Therefore, the study revealed that the self-instructional module was effective in improving the knowledge of staff nurses regarding management of burn injury. By being updated with the knowledge, the Nurses could minimise the infections and other complications related to burn injury and could help the patient to recover with a positive life.

\section{RECOMMENDATION}

- A similar study can be conducted on a larger sample to generalise the study findings.

- A comparative study can be conducted on knowledge of staff nurses and of nursing students regarding management of burn injury.

- A comparative study can be conducted on knowledge of staff nurses having a control group.

- An information booklet can be developed and tested for its effectiveness.

\section{REFERENCES}

1. Ansari Javed, PV Comprehensive Textbook of Medical Surgical nursing, $1^{\text {ST }}$ edition: Jalandhar S. Vikas and Company Medical publisher, 2011, Pp-1264-1302

2. Basavanthappa, BT, Nursing Research, Jaypee Publication, Reprint edition: 2006, Pp-420-25.

3. Basavanthappa, BT, Nursing Theories, $1^{\text {st }}$ edition: Jaypee Brothers, $2007 \mathrm{Pp}-141-48$.

4. Brunner and suddarth's. Textbook of Medical Surgical Nursing, Volume-2, $11^{\text {th }}$ edition: Published by Wolters Kluwer (India) Pvt. Ltd. New Delhi, 2011, Pp-1718-1752

5. Gupta SP, Text book of Statistical Methods, 41 edition: sultan chand and sons publication; 2011, New Delhi.

6. Kothari CR, Research Methodology: Methods and techniques, $2^{\text {nd }}$ edition: Gupta KK, New Delhi, 2003.

7. Lewis, Heitkemper, Dirksen, Medical Surgical Nursing, Assessment and Management of Clinical Problems. $1^{\text {st }}$ edition: Missouri Mosby Elsevier publications, India, Pvt. Ltd, New Delhi, 2011.

8. Long; Barbara C; Phipps; Wilma J; Cassmeyer; Virginia L. Medical- Surgical Nursing A Nursing Process Approach. $3^{\text {rd }}$ ed: Mosby publication; 1993.

9. Polit and Hungler, Nursing Research, $5^{\text {th }}$ edition: JB Lippincott company publication, 1995.

10. Andrew E Dongo, Eshobo E Irekpita, Lilian O Oseghale; A Five-year review of burn injuries in Irrua, Nigeria,2007.

11. Anthony S.P boxy, (2008) M journal of burn injury, 12, Page:- 388-400

12. Ansari- Lari M, Askarian M, (2009), Epidemiology of burn presenting to an emergency department in Shiraz, South Iran burns, Pp:- 579-581.

13. Arnoldo, B. Klein, M and Gibran N, (2010), Practice guidelines for the management of electrical burn, journal of burn care, Pp:-439-447.

14. Baxter CR d et al, (2008) Emergency treatment of burn injury, Ann. Emerg med, Pp:-1305.

15. Clarke JA, 2012, burns in: burn and KG joung AB (ed), The New Aird's Companion in Surgical Studies, London: Churchill lives stone, Pp: - 81-89. The New Aird's Companion in Surgical Studies 